\title{
PENGENALAN CITRA RAMBU LALU LINTAS MENGGUNAKAN EKSTRAKSI FITUR MOMEN- WARNA DAN K-NEAREST NEIGHBOR
}

\author{
Rusma Eko Fiddy Rizarta ${ }^{1}$, Donny Avianto ${ }^{2}$ \\ 1,2 Program Studi Informatika, Fakultas Teknologi Informasi dan Elektro, Universitas Teknologi \\ Yogyakarta, Jln. Siliwangi (Ringroad Utara) Jombor, Sleman, D.I Yogyakarta, 55285, Indonesia \\ E-mail: 'rusma.fiddy@student.uty.ac.id, ${ }^{2}$ donny@staff.uty.ac.id
}

\begin{abstract}
Abstrak
Rambu lalu lintas merupakan salah satu alat perlengkapan jalan dalam bentuk tertentu yang memuat lambang, huruf, angka, kalimat yang digunakan untuk memberikan perintah, larangan, peringatan dan petunjuk bagi pengguna jalan agar tertib berlalu lintas. Namun, banyak di antara pengguna jalan yang belum mengetahui arti dari setiap rambu lalu lintas yang terpasang.Pada penelitian ini, dibuatlah suatu aplikasi yang mampu melakukan klasifikasi citra rambu ke dalam 3 kelas yaitu: peringatan simpang empat prioritas, larangan parkir dan perintah memasuki jalur atau lajur yang ditunjuk. Mula-mula sistem akan melakukan prapemrosesan seperti seperti: grayscalling, histogram equalization, dan segmentasi pada citra input. Selanjutnya, tahap ekstraksi ciri akan dilakukan pada citra hasil pra-pemrosesan. Adapun metode ekstraksi ciri yang digunakan pada penelitian kali ini adalah ekstraksi fitur momen spasial dan pusat ternormalisai (momen) dan ekstraksi fitur statistika warna (warna). Terakhir, nilai fitur yang dihasilkan oleh kedua metode tersebut akan diklasifikasi mengguakan K-Nearest Neighbor. Hasil uji coba menunjukkan bahwa metode ekstraksi fitur gabungan momen-warna memberikan hasil yang menjanjikan. Dari 21 citra latih dan 15 citra uji yang digunakan, sistem mampu mengenali rambu dengan tepat $100 \%$ pada $K=3$, 86,6\% pada $K=5$, dan $86,6 \%$ pada $K=7$.
\end{abstract}

Kata Kunci-Ekstraksi Fitur Momen-Warna, K-Nearest Neighbor, Rambu Lalu Lintas, Citra

\begin{abstract}
The traffic signs are signs with specific shape and symbols, letters, numbers, or words which have the aim to warn or inform the road users. However, there are many road users who are not aware of the meaning of each signs. In this research, we develop an application which can classify a road sign image into three classes, priority four-way crossroad, do-not-park sign, and follow-this-road sign. Initially, the system will do preprocessing step such as grays calling, histogram equalization, and input image segmentation. Next, the feature extraction step will be conducted, namely the spatial moment feature extraction, normalized centering, and color statistics. Lastly, the feature representation from both extraction methods will be used to classify the image using K-nearest neighbor. Experiment result shows that the combination of both feature extraction methods gives promising result. From 21 training images and 15 testing images, the system can recognize the traffic signs with $100 \%$ accuracy with $K=3,86.6 \%$ with $K=5$, and $86.6 \%$ with $K=7$.
\end{abstract}

Keywords—color moment feature extraction, $k$-nearest neighbor, traffic signs, image 


\section{PENDAhuluan}

Pemerintah melalui Kementerian Perhubungan memasang berbagai rambu lalu lintas di jalan raya untuk memberikan informasi terkait kondisi jalan kepada setiap pengguna jalan yang melintas. Berdasarkan Peraturan Menteri Perhubungan Nomor PM 13 tahun 2014, yang dimaksud dengan rambu lalu lintas adalah bagian perlengkapan Jalanyang berupa lambang, huruf, angka, kalimat, dan atau perpaduan yang berfungsi sebagai peringatan, larangan, perintah, atau petunjuk bagi pengguna jalan. Rambu lalu lintas memiliki peranan penting dalam menjaga keselamatan dan ketertiban para pengguna jalan. Pemahaman terhadap arti dari setiap rambu lalu lintas merupakan suatu keharusan bagi seluruh pengguna jalan. Dengan memahami dan mematuhi rambu lalu lintas yang terpasang, diharapkan para pengguna jalan akan terhindar dari hal-hal yang merugikan seperti kecelakaan lalu lintas dan juga akan mengurangi tingkat permasalahan lalu lintas seperti kemacetan.

Namun, seperti yang kita ketahui bersama, tidak semua pengguna jalan memahami arti di balik rambu-rambu lalu lintas yang terpasang. Data yang dirilis oleh Polda Metro Jaya pada Agustus tahun 2017, menunjukkan bahwa jenis pelanggaran lalu lintas yang paling banyak dilakukan oleh pengguna jalan adalah pelanggaran terhadap rambu lalu lintas dengan jumlah mencapai 15.133 kasus pelanggaran. Sebagian besar penyebab kasus pelanggaran tersebut bersumber dari ketidaktahuan pengguna jalan terhadap arti dari rambu lalu lintas yang ada. Dengan kata lain, jumlah tersebut dapat menjadi indikasi banyaknya pengguna jalan yang belum memahami arti rambu-rambu lalu lintas.

Di sisi lain, saat ini mulai banyak penelitian-penelitian tentang auto-pilot, smart car atau autonomous vehicle yang memungkinkan kendaraan dapat berjalan tanpa pengemudi manusia. Salah satu modul penting yang harus dimiliki pada autonomous vehicle adalah pengenalan rambu-rambu lalu lintas secara otomatis [3]. Modul ini biasanya diterapkan dengan menambahkan sensor atau kamera pada mobil yang mampu menangkap citra keadaan jalan raya termasuk di dalamnya adalah rambu lalu lintas. Citra rambu ini kemudian akan dikenali secara otomatis untuk mengatur perilaku kendaraan (kecepatan dan arah melaju) atau diteruskan sebagai informasi bagi penumpang. Dengan modul ini, autonomous vehicle dapat melintas di jalan raya dengan aman dan selamat didasarkan pada pengamatan rambu lalu lintas.

Untuk mengurangi tingkat permasalahan berlalu lintas karena pengguna jalan kurang mengetahui jenis-jenis rambu lalu lintas yang tersebar dan melihat data dari permasalahan tentang pengetahuan rambu lalu lintas, maka peneliti memiliki ide untuk membangun sebuah aplikasi pengenalan citra dari rambu lalu lintas dengan mengimplementasikan metode $K$ Nearest Neighbor dan Euclidean Distance untuk mengenali citra atau gambar dari rambu lalu lintas yang terpasang. Aplikasi yang dibangun diharapkan dapat memberikan pengetahuan kepada masyarakat tentang arti dari rambu lalu lintas yang memiliki bentuk bermacam-macam di jalan raya hanya dengan memasukkan citra yang terpasang di jalan raya serta penerapan teknologi computer vision pada kehidupan sehari-hari. Rambu lalu lintas yang akan digunakan pada penelitian yaitu peringatan simpang empat prioritas, larangan parkir, dan perintah memasuki jalur atau lajur yang ditunjuk.

Beberapa penelitian yang menjadi referensi dalam penelitian ini diantaranya: referensi pertama menggunakan metode (GLCM) dan Euclidean Distance untuk menentukan selisih kemiripan citra uji batik dan citra training. Hasil dari penelitian mendapatkan akurasi $77 \%$ pada recall $37.75 \%$ dan akurasi $82 \%$ pada recall $30.26 \%$ [6]. Referensi kedua yaitu penelitian dengan menerapkan metode jarak City-Block dan ekstraksi fitur vektor untuk pengenalan citra rambu lalu lintas berbentuk lingkaran. Hasil dari penelitian menunjukkan tingkat akurasi tertinggi yaitu 88\% pada ukuran citra 50x50 piksel [7]. Referensi yang ketiga mengacu pada penelitian yang 
mengimplementasikan metode K-Nearest Neigbor dan Gray Level Coocurence Matrix (GLCM). Citra diubah menjadi grayscale dan hasil data grayscale di-scaling menjadi 6 level dan dicari GLCM dengan derajat searah $0^{\circ}, 45^{\circ}, 90^{\circ}, 135^{\circ}$ dan jarak piksel 1, 2, 3, 4, dan 5 . Ekstraksi fitur yang digunakan yaitu kontras, korelasi, energi dan homogenitas. Hasil dari penelitian ini didapat akurasi tertinggi pada sudut $45^{\circ}$ yaitu $57,74 \%$ dan akurasi tertinggi menggunakan jarak piksel 3 yaitu 52,17\% dengan jumlah data training dan testing 150 dan 60 [8]. Referensi keempat membahas tentang pendeteksi rambu lalu lintas berdasarkan bentuk dengan menggunakan operator Sobel dan metode Hamming untuk mencari kemiripan citra yang terdapat dalam database. Berdasarkan hasil uji coba menggunakan 10 citra uji yang berbeda didapat akurasi sebesar $100 \%$ dan disimpulkan operator Sobel dan metode Hamming dapat mendeteksi bentuk rambu lalu lintas [10].

\section{METODOLOGI PENELITIAN}

\subsection{Metodologi Penelitian}

a. Studi Pustaka

Studi pustaka dilakukan untuk mendapatkan teori acuan, informasi dan referensi dalam kegiatan penelitian. Sehingga dapat digunakan sebagai pengetahuan dasar dalam pengolahan citra rambu lalu lintas, algoritma metode K-Nearest Neighbor dan perhitungan jarak Euclidean Distance.

b. Kegiatan pengumpulan data rambu lalu lintas untuk menentukan hasil keluaran program didapat dari Peraturan Menteri Perhubungan Nomor PM 13 tahun 2014 di Dinas Perhubungan Kabupaten Sleman. Proses pengumpulan citra rambu lalu lintas dilakukan dengan mengambil foto secara langsung. Terdapat dua cara yang dilakukan dalam pengumpulan citra rambu lalu lintas yaitu:

- Citra rambu lalu lintas yang digunakan untuk data latih (training) atau data sampel dibuat dari cetakan kertas kemudian difoto dengan latar belakang yang berbeda.

- Citra rambu lalu lintas yang digunakan untuk pengujian aplikasi diambil langsung pada rambu yang terpasang di jalan pada kondisi siang hari. Pengambilan citra uji langsung di lapangan merupakan tujuan utama dari aplikasi bahwa mampu mengenali atau mengindentifikasi jenis rambu yang telah terpasang di jalan umum.

c. Perancangan Sistem

Rancangan sistem pada penelitian ini meliputi beberapa tahapan proses, yaitu rancangan terhadap alur kerja program atau flowchart, DAD, ERD, rancangan terhadap preprocessing citra, pengolahan citra atau segmentasi, ekstraksi fitur citra, rancangan antarmuka data latih citra dan pengujian rambu lalu lintas menggunakan $K$-Nearest Neighbor dan perhitungan jarak Euclidean Distance.

d. Implementasi

Implementasi dilakukan dengan menggunakan bahasa pemrograman Java dan basis data MySQL. Bahasa pemrograman Java adalah salah satu bahasa pemrograman yang menggunakan konsep Object Oriented Programming (OOP) sehingga mempermudah dalam pembuatan kelas-kelas perhitungan atau pengolahan citra.

e. Pengujian

Tahapan ini dilakukan untuk mengetahui apakah hasil analisis telah sesuai dengan yang diharapkan atau belum. Pengujian juga dilakukan untuk mengetahui ada tidaknya kesalahan atau error dari sistem yang dibuat dengan mengamati hasil eksekusi melalui data uji dan memeriksa fungsionalitas perangkat lunak atau hasil perhitungan. Pengujian sistem menggunakan citra rambu lalu lintas sebanyak 36 buah, dengan masing-masing rambu memiliki 7 citra latih dan 5 citra uji. 


\subsection{Sistem Yang Diusulkan}

Sistem yang diusulkan pada penelitian kali ini bertujuan untuk mengenali citra rambu lalu lintas dengan mengimplementasikan metode K-Nearest Neighbor dan perhitungan jarak Euclidean Distance. Rambu lalu lintas yang diproses merupakan hasil pengambilan gambar dari handphone atau smartphone yang kemudian dimasukkan ke dalam aplikasi desktop. Secara umum, jalannya sistem yang diusulkan dapat dilihat pada Gambar 1.

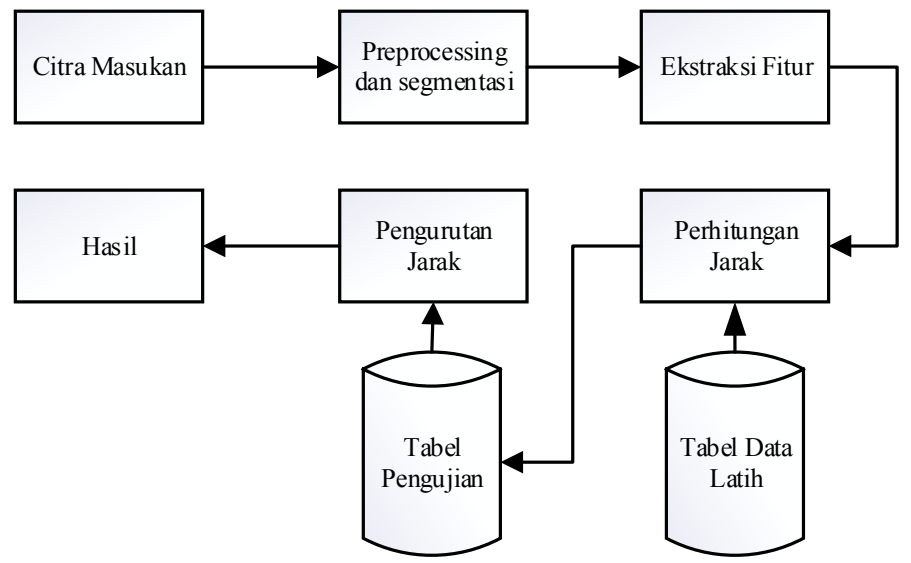

Gambar 1 Prinsip Pengenalan Citra

Berdasarkan Gambar 1 di atas, tahapan pertama dari sistem yang diusulkan adalah prapemrosesan terhadap citra input.Pada tahap ini mula-mula citra input akan diubah ukurannya (resizing) menjadi 256x256 piksel dengan tujuan agar proses pengolahan citra lebih cepat, selanjutnya citra di konversi menjadi bentuk grayscale, ekualisasi histogram, penajaman citra (sharpening), konversi citra biner dan segmentasi dilasi dan erosi untuk mendapatkan nilai hasil ekstraksi fitur momen spasial dan momen pusat ternormalisasi. Sedangkan untuk ekstraksi statistika warna masih menggunakan citra asli yang telah di resize.Nilai fitur yang sudah diperoleh akan disimpan ke basis data. Pada pengujian citra, fitur yang diperoleh akan dibandingkan dengan semua objek data latih yang sudah disimpan dan dilakukan perhitungan jarak. Hasil jarak akan diberikan ranking atau peringkat. Seluruh peringkat akan diurutkan dari nilai terkecil ke nilai terbesar. Objek yang memiliki peringkat paling rendah atau kecil merupakan citra yang mirip dan dijadikan hasil berupa informasi dari data rambu lalu lintas seperti kategori tabel rambu, nomor rambu, nama rambu, nama tipe dan arti rambu.

\section{LANDASAN TEORI}

\subsection{K-Nearest Neighbor}

K-Nearest Neighbor (KNN) adalah sebuah metode untuk melakukan klasifikasi terhadap suatu objek berdasarkan data pembelajaran yang memiliki jarak paling dekat dengan objek tersebut. Data pembelajaran alam diproyeksikan ke dalam K ruang berdimensi banyak, yang masing-masing dimensi merepresentasikan fitur dari data. Ruang ini akan dibagi-bagi menjadi suatu bagian berdasarkan klasifikasi yang telah dilakukan terhadap data pembelajaran [9].

Langkah-langkah yang dilakukan untuk pada metode K-Nearest Neigbor adalah sebagai berikut:

a. Generate data sampel yang akan digunakan sebagai data training.

b. Inialisasi K titik sebagai titik pusat (centroid) awal.

c. Hitung jarak setiap objek data set dengan data training dengan rumus perhitungan Euclidean Distance. 
Classifier atau klasifikasi berasumsi jarak catatan dari satu dengan yang lainnya sebagai kriteria untuk kedekatan mereka dan memilih catatan paling mirip. Ada banyak metode untuk menghitung jarak seperti fungsi jarak Euclidean, Manhattan, dan lain-lain.

\subsection{Euclidean Distance}

Euclidean Space diperkenalkan oleh Euclid, seorang matematikawan dari Yunani sekitar tahun 300 BCE. Euclidean Distance adalah jarak antara dua titik yang dapat diukur dan dihasilkan oleh formula Pytagoras dan untuk mempelajari hubungan antara sudut dan jarak. Euclidean vector atau sering hanya disebut dengan vector adalah objek geometri yang memiliki panjang (magnitude) dan arah (direction). Sedangkan ruang vektor adalah sebuah struktur matematika yang dibentuk oleh sekumpulan vektor. Vektor-vektor tersebut dapat ditambahkan, dikalikan dengan bilangan real dan lain-lain. Untuk menghitung jarak antara vektor A dan vektor $\mathrm{B}$ digunakan persamaan euclidean distance.

Metode Euclidean Distance adalah suatu metode pencarian kedekatan nilai jarak dari 2 buah variabel atau lebih. Selain mudah, metode ini juga tidak memakan waktu dan proses yang cepat. Karena berkaitan dengan teori Pytagoras biasanya Euclidean diterapkan pada 1, 2, dan 3 dimensi. Tapi dapat diterapkan pada dimensi yang lebih tinggi. Berikut persamaan pehitungan dari Euclidean Distance yang digunakan dalam penelitian:

$$
\operatorname{jarak}(i)=\sqrt{\left(X_{i}-X_{u j i}\right)^{2}+\left(Y_{i}-Y_{u j i}\right)^{2}}
$$

Keterangan :

$\mathrm{i}=$ data latih ke-i

uji $\quad=$ data uji

$\mathrm{X}=$ vektor atau ekstraksi fitur $\mathrm{X}$ yaitu momen spasial dan momen pusat ternormalisasi

$\mathrm{Y} \quad=$ vektor atau ekstraksi fitur $\mathrm{Y}$ yaitu statistika warna

$\operatorname{Jarak}(\mathrm{i})=$ tingkat perbedaan atau jarak

\subsection{Preprocessing}

Preprocessing adalah proses awal dilakukannya perbaikan citra sebelum dilakukan proses lebih lanjut terhadap citra masukan. Preprocessing bertujuan supaya meningkatkan kemungkinan keberhasilan pada tahap pengolahan lebih lanjut pada sebuah citra. Preprocessing merupakan suatu proses untuk menghilangkan bagian-bagian yang tidak diperlukan pada gambar input untuk proses selanjutnya [2]. Dalam pengolahan citra, citra berwarna seringkali harus dikonversi ke dalam bentuk citra berskala keabuan (Grayscale) atau citra biner (hitamputih). Mengingat kedua citra ini yang mudah diinterpretasikan [5]. Berikut beberapa preprocessing yang dilakukan:

\subsubsection{Grayscale}

Untuk mengubah citra berwarna Red (R), Green (G), dan Blue (B) menjadi citra skala abu-abu (Grayscale) menggunakan persamaan sebagai berikut [5] :

$$
C G=(R \times 0,2989)+(G \times 0,5870)+(B \times 0,1141)
$$

Keterangan:

$$
\begin{array}{ll}
\mathrm{CG} & =\text { Citra Grayscale } \\
\mathrm{R} & =\text { nilai piksel red }(\text { merah) } \\
\mathrm{G} & =\text { nilai piksel green }(\text { hijau) } \\
\mathrm{B} & =\text { nilai piksel blue }(\text { biru) }
\end{array}
$$




\subsubsection{Ekualisasi Histogram (Histogram Equalization)}

Tujuan dari perataan histrogram adalah untuk memperoleh penyebaran aras keabuan yang merata, sehingga setiap derajat keabuan memiliki jumlah piksel yang relatif sama [1]. Akumulasi histogram untuk piksel beraras k dinyatakan pada persamaan 2 dengan $i$ bernilai 0 , $1,2,3, \ldots ., \mathrm{L}-1$ dengan $\mathrm{L}$ menyatakan jumlah aras keabuan.

$$
c[k+1]=\sum_{i=1}^{k} h i s t[k+1]
$$

Selanjutnya aras keabuan $k$ akan diganti dengan $a$ melalui persamaan sebagai berikut dengan $\mathrm{N}$ menyatakan jumlah piksel citra.

$$
a_{k}=\operatorname{round}(L-1) \frac{c[k+1]}{N}
$$

\subsubsection{Thresholding}

Thresholding adalah proses mengubah citra berderajat keabuan (grayscale) menjadi citra biner atau hitam-putih sehingga dapat diketahui daerah mana yang termasuk objek dan background dari citra secara jelas [4].

Keterangan :

$$
B(i)=\left\{\begin{array}{l}
0, i \geq T \\
1, i<T
\end{array}\right.
$$

$$
\begin{array}{ll}
\mathrm{B}(\mathrm{i}) & =\text { citra biner } \\
\mathrm{i} & =\text { Intensitas citra } \\
\mathrm{T} & =\text { Threshold }
\end{array}
$$

\subsection{Ekstraksi Fitur}

Fitur suatu objek merupakan karakteristik yang melekat pada objek. Fitur bentuk merupakan suatu fitur yang diperoleh melalui bentuk objek dan dapat dinyatakan melalui kontur, area dan transformasi. Fitur bentuk biasa digunakan untuk kepentingan identifikasi objek [5].

\subsubsection{Statistika Warna}

Fitur warna dapat diperoleh dari perhitungan statistis seperti rerata dan deviasi standar. Perhitungan dikenakan pada setiap komponen R, G dan B.

Rerata memberikan ukuran mengenai distribusi dan dihitung dengan:

Keterangan:

$$
\mu=\frac{1}{M N} \sum_{i=1}^{M} \sum_{j=1}^{N} P_{i j}
$$

$\mu \quad=$ rata-rata

$\mathrm{N} \quad=$ Baris piksel

$\mathrm{M} \quad=$ kolom piksel

$\mathrm{P} \quad=$ intensitas komponen RGB

$\mathrm{MN} \quad=$ jumlah piksel

Varians menyatakan luas sebaran distribusi. Akar kuadrat varians dinamakan sebagai standar deviasi. Standar deviasi terdapat pada persamaan 5.

Keterangan:

$$
\sigma=\sqrt{\frac{1}{M N} \sum_{i=1}^{M} \sum_{j=1}^{N}\left(P_{i j}-\mu\right)^{2}}
$$

$$
\begin{array}{ll}
\sigma & =\text { varians } \\
\mu & =\text { rata-rata } \\
\mathrm{N} & =\text { Baris piksel } \\
\mathrm{M} & =\text { kolom piksel } \\
\mathrm{P} & =\text { intensitas komponen RGB } \\
\mathrm{MN} & =\text { jumlah piksel }
\end{array}
$$




\subsubsection{Momen Spasial dan Momen Pusat Ternormalisasi}

Persamaan momen spasial yaitu:

$$
M_{p q}=\sum_{x=0}^{M-1} \sum_{x=0}^{N-1} x^{p} y^{p} i(x, y)
$$

Keterangan :

$\mathrm{p}, \mathrm{q}=0,1,2, .$. dengan $\mathrm{p} \mathrm{q}$ menyatakan orde momen adalah integer

$\mathrm{M}$ menyatakan jumlah kolom citra

$\mathrm{N}$ menyatakan jumlah baris citra

$\mathrm{x}$ adalah ordinat piksel

$\mathrm{y}$ adalah absis piksel

$\mathrm{i}(\mathrm{x}, \mathrm{y})$ menyatakan intensitas aras keabuan piksel $(\mathrm{x}, \mathrm{y})$

Momen pusat adalah momen spasial yang dihitung relatif terhadap pusat massa. Persamaan momen pusat yaitu :

$$
\mu_{p q} \sum_{x=0}^{M-1} \sum_{y=0}^{N-1}(x-\bar{x})^{p}(y-\bar{y})^{q} i(x, y)
$$

Momen diatas bersifat invariant (tidak terpengaruhi) terhadap translasi. Dalam hal ini, $\bar{x}$ dan $\bar{y}$ diperoleh melalui :

$$
\bar{x}=\frac{M_{10}}{M_{00}}, \bar{y}=\frac{M_{10}}{M_{00}}
$$

Agar momen pusat bersifat bebas terhadap translasi, penyekalan, dan rotasi, maka momen perlu dinormalisasi. Persamaan momen ternormalisasi yaitu :

$$
\mathrm{\eta}_{p q}=\frac{\mu_{p q}}{\mu_{00}^{y}}, \gamma=\frac{p+q+2}{2}
$$

\subsection{Perhitungan Nilai Akurasi}

Persamaan untuk mencari tingkat akurasi hasil pengenalan citra uji yaitu :

$$
\text { Akurasi }=\frac{\text { Jumlah Citra Dikenali }}{\text { Jumlah Citra Uji K }} \times 100
$$

\subsection{Hasil}

\section{HASIL DAN PEMBAHASAN}

Aplikasi yang dibangun digunakan untuk mengenali citra rambu lalu lintas dengan mengimplementasikan metode K-Nearest Neighbor dan perhitungan jarak Euclidean Distance. Rambu lalu lintas yang diproses merupakan hasil pengambilan gambar dari handphone / smartphone yang kemudian dimasukkan ke dalam aplikasi desktop.

\subsubsection{Kebutuhan Sistem} yaitu :

Berikut beberapa proses yang dilakukan untuk memenuhi kebutuhan pengguna aplikasi

a. Menyimpan data rambu lalu lintas yang memuat informasi arti rambu lalu lintas, nomor rambu, tabel rambu, nama tipe dan gambar atau simbol rambu lalu lintas.

b. Melakukan pengolahan citra dari data latih atau data uji yang dimasukkan.

c. Dapat mengatur threshold jika citra hasil atau citra biner yang akan di ekstraksi kurang maksimal (mengandung derau).

d. Melakukan atau menghitung ekstraksi fitur dari data latih atau data uji.

e. Menyimpan hasil ekstraksi fitur ke basis data. 
f. Menentukan nilai $\mathrm{K}$ yaitu 3, 5 dan 7 saat pengujian citra.

g. Menghitung jarak data uji dengan data latih menggunakan Euclidean Distance dan melakukan pengurutan jarak nilai terkecil ke terbesar untuk mendapatkan peringkat.

h. Menentukan keputusan klasifikasi dan memberikan informasi hasil rambu yang dapat dikenali sistem.

i. Menambahkan petunjuk atau bantuan kepada pengguna bagaimana citra hasil biner yang sesuai atau citra yang seharusnya memperlihatkan objek rambu

\subsubsection{Flowchart}

Pada aplikasi pengenalan citra rambu lalu lintas ini untuk proses pengolahan masukkan citra berupa gambar yang akan dilakukan dengan cara-cara sesuai teori yang telah dipelajari, sedangkan untuk proses pengenalan akan diberikan nilai K dan perhitungan Euclidean Distance yang akan disajikan pada flowchart.

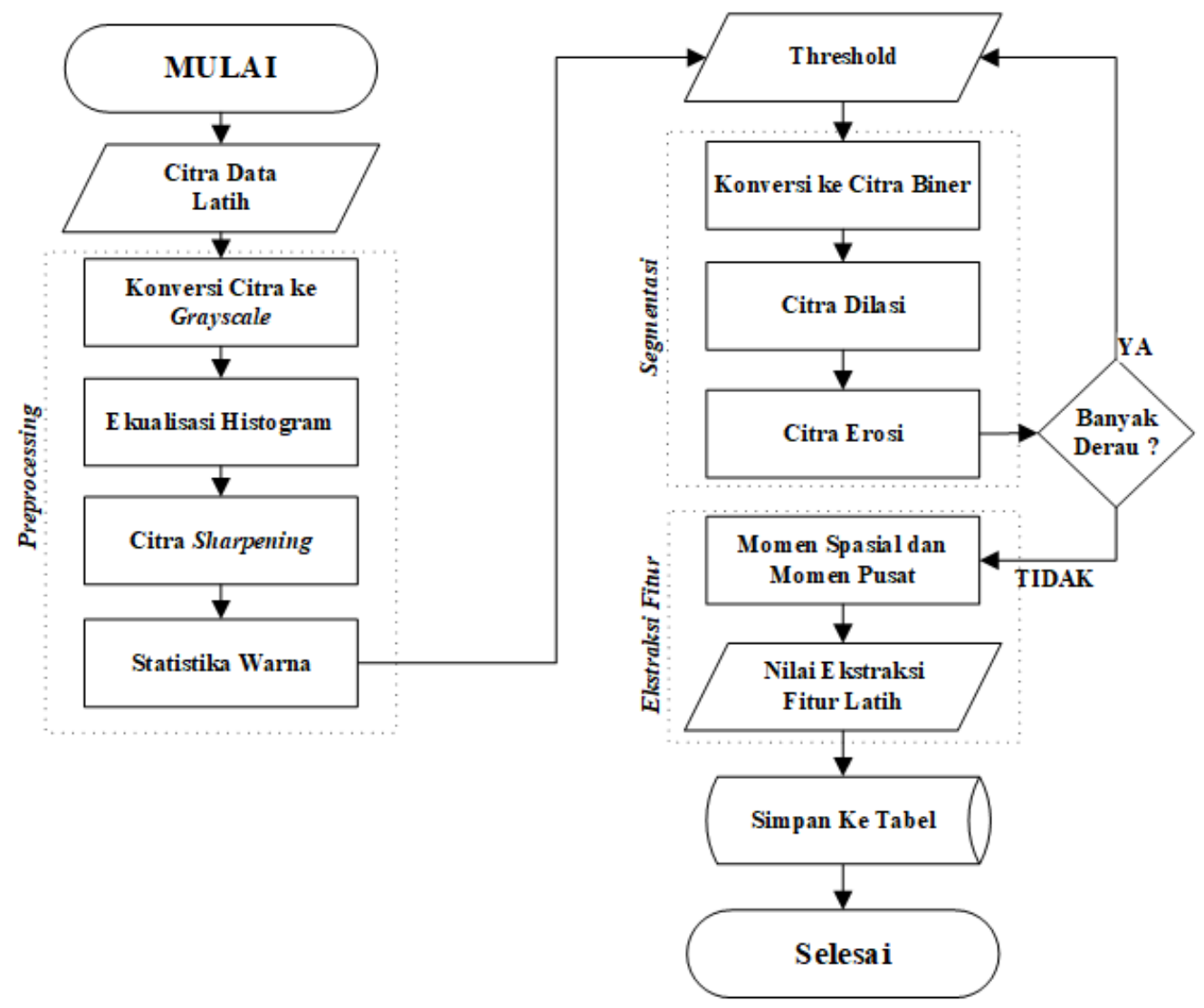

Gambar 2 Flowchart Data Latih 


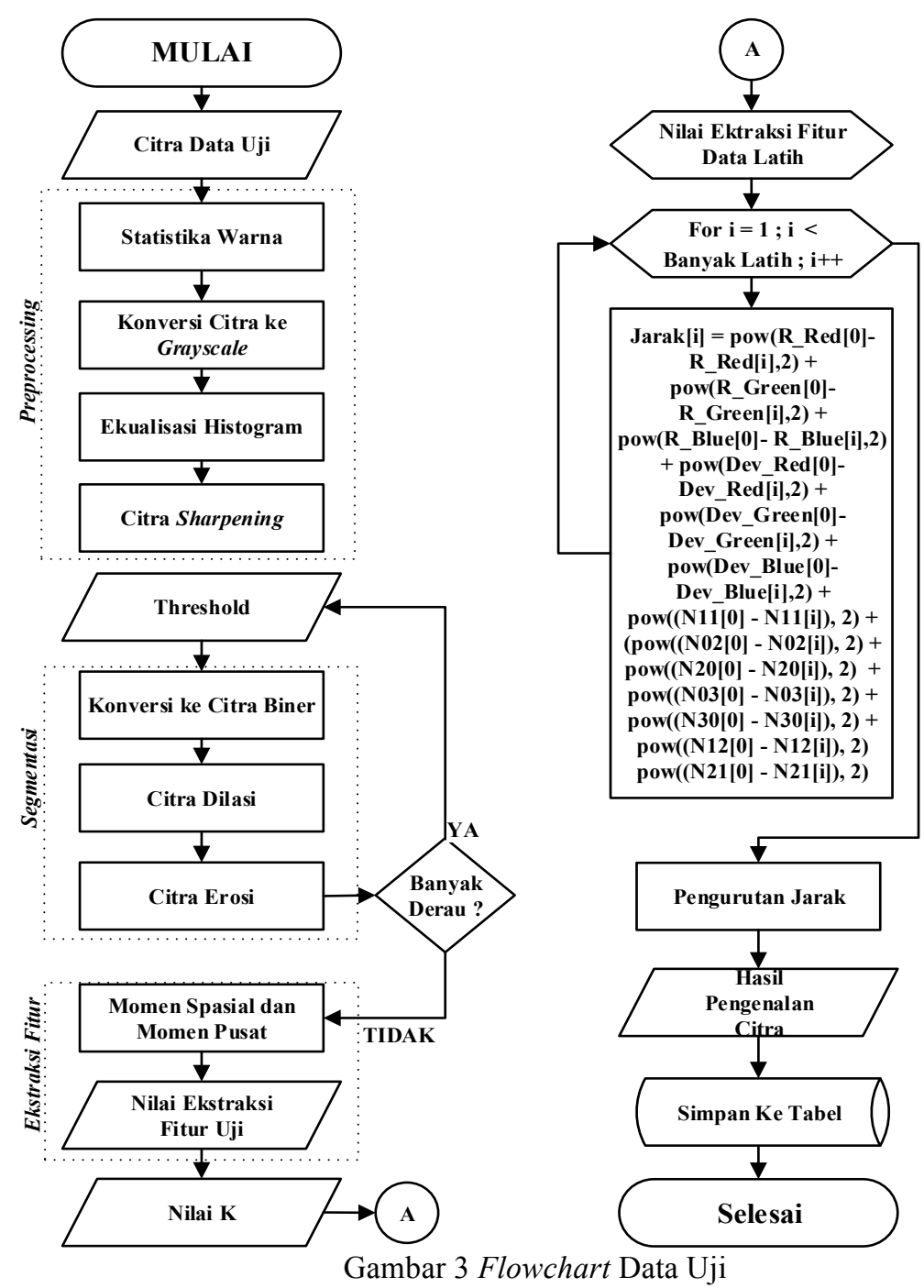

\subsection{Pembahasan}

Aplikasi bertujuan untuk mengenali salah satu rambu lalu lintas dari tiga rambu lalu lintas yang digunakan yaitu peringatan simpang empat prioritas, larangan parkir, dan perintah memasuki jalur atau lajur yang ditunjuk yang terpasang dijalan. Proses pengenalan citra diawali dengan memproses semua data citra data latih yang masing-masing jenis rambu memiliki tujuh buah citra data latih yang telah dimasukkan ke dalam sistem, jumlah citra atau data latih yaitu sebanyak 21 citra. Citra-citra yang dimasukkan tersebut diolah dengan menggunakan metode pengolahan citra yang terdiri dari konversi ke bentuk grayscale, ekualisasi histogram, konversi ke bentuk biner, proses dilasi dan erosi. Hasil akhir dari pemrosesan gambar, selanjutnya digunakan untuk mendapatkan nilai ektraksi fitur statistika warna, momen pusat dan momen spasial dan disimpan ke dalam basis data.

\subsubsection{Implementasi}

Implementasi pada aplikasi yaitu memasukkan data rambu lalu lintas sebagai informasi hasil pengenalan citra, implementasi data latih, implementasi pengujian citra dan melihat hasil akurasi dari pengenalan citra uji. Selain itu, implementasi tampilan dibuat cukup sederhana yang bertujuan pengguna aplikasi tidak kesulitan ketika akan melakukan pengujian citra rambu lalu lintas. 
a. Tampilan Antar Muka Data Latih

Tampilan data latih merupakan menu untuk memasukkan citra latih hingga proses akhir yaitu nilai ekstraksi fitur. Selain itu, data ekstraksi fitur citra latih akan digunakan untuk perhitungan jarak Euclidean Distance dengan citra uji. Pengguna memasukkan citra melalui kotak dialog buka gambar, kemudian menentukan target rambu lalu lintas, proses ekstraksi fitur dan simpan nilai. Saat pengguna memasukkan citra dengan klik icon buka gambar, nilai threshold akan otomatis terisi berdasarkan perhitungan statistika, namun jika hasil citra biner dirasa kurang sesuai pengguna dapat mengatur threshold sendiri.

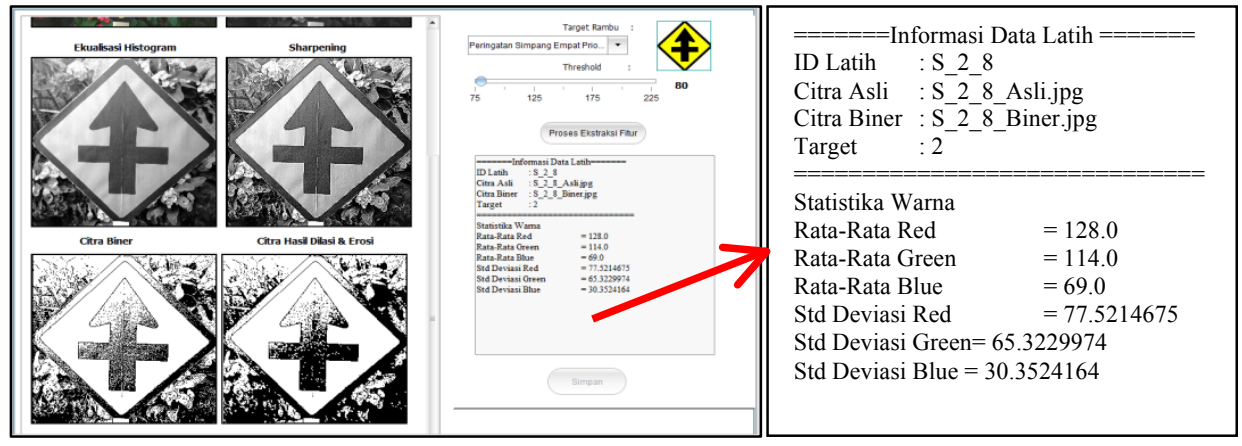

Gambar 4 Tampilan Antar Muka Data Latih

b. Tampilan Antar Muka Pengujian Citra

Tampilan menu pengujian citra pada gambar 6 merupakan menu yang digunakan oleh pengguna untuk melakukan pengenalan citra uji. Pengguna diminta untuk memasukkan citra uji melalui icon buka gambar. Citra hasil pengolahan yaitu citra biner akan otomatis tampil di sebelah kanan icon buka gambar, jika hasil kurang sesuai pengguna dapat mengatur threshold sendiri. Secara garis besar, proses pengolahan citra pada menu pengujian sama seperti pada data latih.

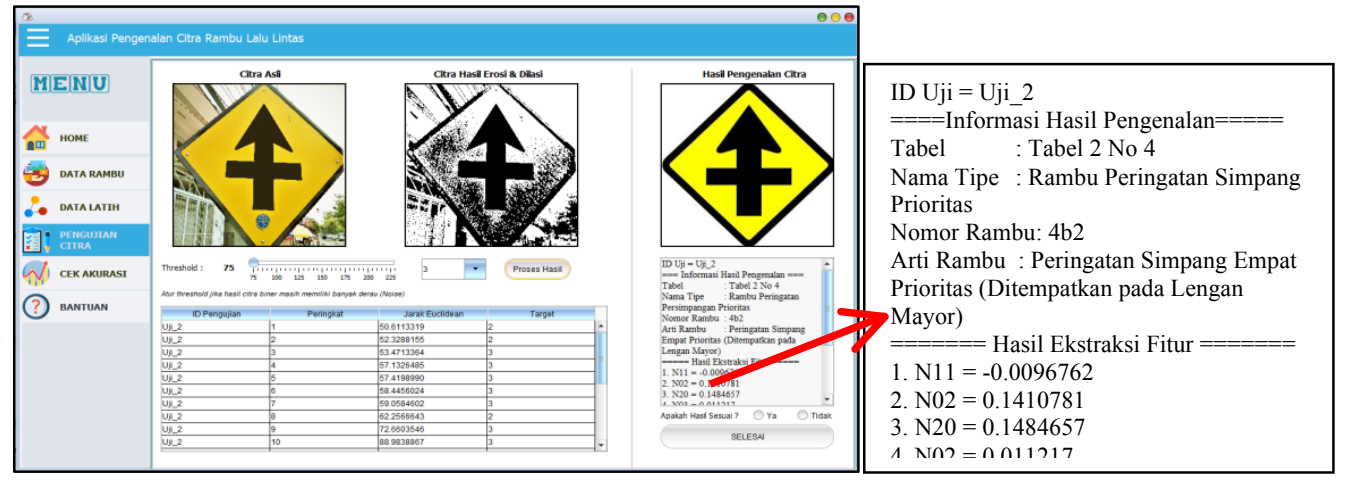

Gambar 5 Tampilan Antar Muka Pengujian Citra

\subsubsection{Pembahasan Flowchart}

Pembahasan ini meliputi pengolahan citra dan mendapatkan nilai-nilai ekstraksi fitur pada aplikasi. Berikut merupakan tahapan awalyaitu proses pengolahan citra berdasarkan flowchart, mula mula masukkan citra asli ke dalam aplikasi, kemudian akan dilakukan proses resizing atau mengubah ukuran menjadi 256x256 piksel untuk selanjutnya di konversi ke citra grayscale yang ditunjukkan pada gambar 6. Citra asli pada tahap awal akan dilakukan ektraksi fitur statistika warna, karena setiap pengolahan citra disimpan pada variabel yang berbeda maka citra lain nilainya tidak akan terpengaruh. 
(a)

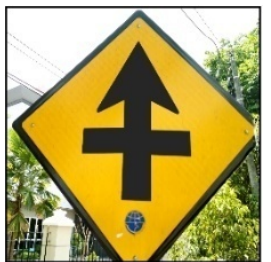

(b)

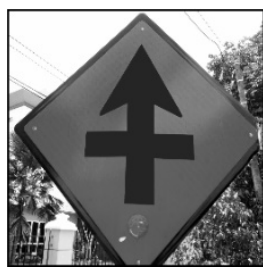

Gambar 6 Citra Asli (a) dan Citra Hasil Grayscale (b)

Selanjutnya, dari citra grayscale akan diproses ekualisasi histogram untuk mendapatkan sebaran intensitas yang merata. Dari citra ekualisasi histogram akan dilakukan proses penajaman citra (sharpening) yang bertujuan untuk mempertajam setiap tepi dari objek, perbedaan hasil pada penajaman citra terlihat pada tepian tanda panah atau simbol rambu lalu lintas terdapat garis putih. Hasil dari proses tersebut ditunjukan pada gambar 7 .

(a)

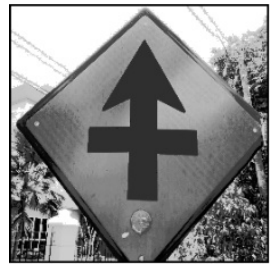

(b)

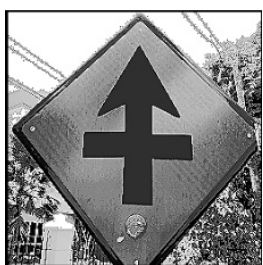

Gambar 7 Citra Hasil Ekualisasi Histogram (a) dan Hasil Sharpening (b)

Karena ekstraksi fitur yang digunakan adalah momen spasial dan momen pusat maka perlu dilakukan segmentasi citra, dari citra hasil sharpening akan di proses menjadi citra biner. Selanjutnya citra biner akan dilakukan proses dilasi dan erosi untuk mengurangi derau (noise) yang terdapat pada citra. Citra hasil erosi merupakan citra yang akan diambil ektraksi fiturnya. Berikut hasil dari pengolahan ditunjukan pada gambar 8 .

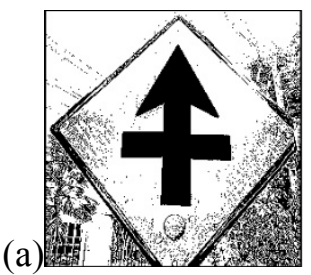

(b)
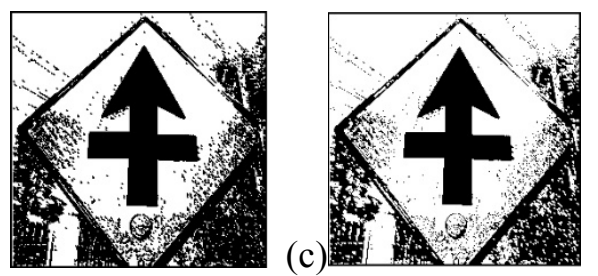

Gambar 8 Citra Biner (a), Citra Hasil Dilasi (b) dan Citra Hasil Erosi (c)

Jika semua pengolahan citra dan ekstraksi fitur pada data latih selesai, maka program akan menyimpan nilai-nilai ke basis data. Untuk proses pengujian citra, hasil nilai ekstraksi fitur statistika warna, momen spasial dan pusat dari citra uji akan dihitung jaraknya dengan ektraksi fitur data latih yang telah tersimpan ke basis data menggunakan persamaan 1 euclidean distance.

\subsubsection{Pengujian}

\subsubsection{Pengujian Segmentasi Citra}

Pengujian segmentasi dilakukan untuk mendapatkan hasil citra biner yang baik dalam memisahkan objek citra dari latar belakang yang dapat mengganggu proses ektraksi fitur. Karena proses konversi citra grayscale ke citra biner saja kurang cukup, maka peneliti menambahkan proses dilasi dan erosi pada citra. Threshold awal yang diberikan bernilai 160, berikut hasil citra biner pada gambar 9 (a) dan terlihat pada pojok atas citra terdapat derau (noise) yang mengganggu objek citra gambar 9 (b). 
(a)

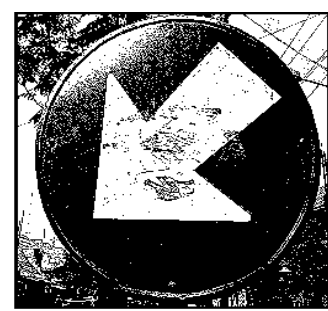

(b)

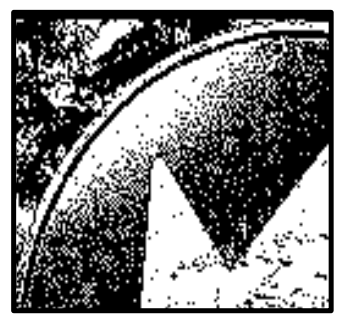

Gambar 9 Citra Biner (a) dan Derau Pada Citra Biner (b)

Karena hasil konversi citra biner dengan threshold 160 masih terdapat derau, maka dilakukan proses dilasi untuk memperlebar aras citra bernilai 1. Berikut hasil yang didapat ditunjukan pada gambar 10 (a) yang mana bercak atau derau warna putih yang lebar tadi sudah tertutup oleh warna hitam. Kemudian citra hasil dilasi juga masih terdapat warna hitam yang menutupi objek citra gambar 10 (b) atau warna hitam yang masih lebar penyebarannya, maka selanjutnya diberikan proses penipisan (erosi) citra bewarna hitam sehingga bercak derau menjadi tipis penyebarannya di dalam objek dengan hasil pada gambar 10 (c).

(a)

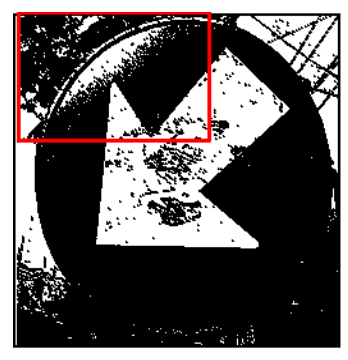

(b)

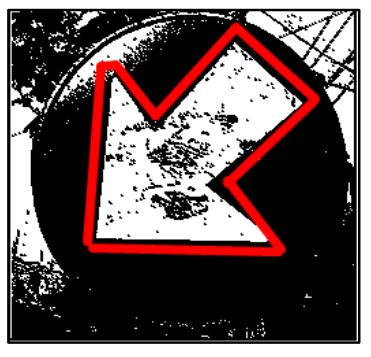

(c)

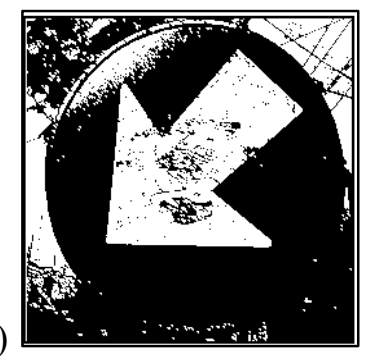

Gambar 10 Perbandingan Hasil Citra Dilasi (a), Derau pada objek (b) Dan Hasil Erosi (c)

\subsubsection{Pengujian Ekstraksi FiturStatistika Warna, Momen Spasial-Pusat}

Tahapan ini bertujuan untuk melihat metode pengaruh metode ekstraksi fitur yang digunakan terhadap kemampuan sistem dalam mengenali objek rambu lalu lintas.Terdapat 2 metode ekstraksi fitur yang terlibat pada tahap ini, yaitu ekstraksi fitur statistika warna (SW) dan ekstraksi fitur momen spasial-pusat (MSP). Kedua metode tersebut diterapkan pada seluruh citra uji. Citra uji yang digunakan berjumlah 15 citra, terdiri dari 5 citra rambu peringatan simpang empat prioritas, 5 citra rambu larangan parkir, dan 5 citra rambu perintah memasuki jalur yang ditunjuk. Setelah melakukan ekstraksi fitur terhadap citra uji, sistem akan melanjutkan ke tahap klasifikasi menggunakan metode KNN. Pada penelitian ini, digunakan 3 nilai $\mathrm{K}$ yaitu $\mathrm{K}=3, \mathrm{~K}=5$, dan $\mathrm{K}=7$ dalam rangka mencari nilai akurasi yang tertinggi. Hasil dari tahap pengujian ini dapat terangkum pada Tabel 1 dan Tabel 2.

Tabel 1Presentase Pengenalan Citra

\begin{tabular}{|c|c|c|c|c|c|c|c|c|c|c|}
\hline \multirow{3}{*}{$\begin{array}{c}\text { Citra } \\
\text { Uji ke- }\end{array}$} & \multirow{3}{*}{ Threshold } & \multicolumn{9}{|c|}{ Metode Ekstraksi Fitur } \\
\hline & & \multicolumn{3}{|c|}{ MSP } & \multicolumn{3}{|c|}{ SW } & \multicolumn{3}{|c|}{$\mathbf{M S P}+\mathbf{S W}$} \\
\hline & & $K=3$ & $K=5$ & $K=7$ & $K=3$ & $K=5$ & $K=7$ & $K=3$ & $K=5$ & $K=7$ \\
\hline 1 & 100 & $x$ & $x$ & $\checkmark$ & $\checkmark$ & $\checkmark$ & $\checkmark$ & $\checkmark$ & $\checkmark$ & $\checkmark$ \\
\hline 2 & 75 & $\checkmark$ & $\checkmark$ & $\checkmark$ & $\checkmark$ & $x$ & $x$ & $\checkmark$ & $x$ & $x$ \\
\hline 3 & 75 & $x$ & $x$ & $\checkmark$ & $\checkmark$ & $\checkmark$ & $\checkmark$ & $\checkmark$ & $\checkmark$ & $\checkmark$ \\
\hline 4 & 75 & $x$ & $x$ & $\checkmark$ & $\checkmark$ & $x$ & $x$ & $\checkmark$ & $x$ & $x$ \\
\hline 5 & 80 & $x$ & $x$ & $\checkmark$ & $\checkmark$ & $\checkmark$ & $\checkmark$ & $\checkmark$ & $\checkmark$ & $\checkmark$ \\
\hline 6 & 170 & $\checkmark$ & $\checkmark$ & $\checkmark$ & $\checkmark$ & $\checkmark$ & $\checkmark$ & $\checkmark$ & $\checkmark$ & $\checkmark$ \\
\hline 7 & 170 & $\checkmark$ & $x$ & $x$ & $\checkmark$ & $\checkmark$ & $\checkmark$ & $\checkmark$ & $\checkmark$ & $\checkmark$ \\
\hline 8 & 170 & $\checkmark$ & $x$ & $x$ & $\checkmark$ & $\checkmark$ & $\checkmark$ & $\checkmark$ & $\checkmark$ & $\checkmark$ \\
\hline 9 & 170 & $\checkmark$ & $x$ & $x$ & $\checkmark$ & $\checkmark$ & $\checkmark$ & $\checkmark$ & $\checkmark$ & $\checkmark$ \\
\hline
\end{tabular}




\begin{tabular}{|c|c|c|c|c|c|c|c|c|c|c|}
\hline 10 & 160 & $\checkmark$ & $\checkmark$ & $\checkmark$ & $\checkmark$ & $\checkmark$ & $\checkmark$ & $\checkmark$ & $\checkmark$ & $\checkmark$ \\
\hline 11 & 120 & $x$ & $x$ & $x$ & $\checkmark$ & $\checkmark$ & $\checkmark$ & $\checkmark$ & $\checkmark$ & $\checkmark$ \\
\hline 12 & 160 & $x$ & $x$ & $x$ & $\checkmark$ & $\checkmark$ & $\checkmark$ & $\checkmark$ & $\checkmark$ & $\checkmark$ \\
\hline 13 & 148 & $\checkmark$ & $x$ & $\checkmark$ & $\checkmark$ & $\checkmark$ & $\checkmark$ & $\checkmark$ & $\checkmark$ & $\checkmark$ \\
\hline 14 & 160 & $x$ & $\checkmark$ & $x$ & $\checkmark$ & $\checkmark$ & $\checkmark$ & $\checkmark$ & $\checkmark$ & $\checkmark$ \\
\hline 15 & 130 & $x$ & $\checkmark$ & $x$ & $\checkmark$ & $\checkmark$ & $\checkmark$ & $\checkmark$ & $\checkmark$ & $\checkmark$ \\
\hline \multicolumn{2}{|c|}{ Rata-rata akurasi } & $46,7 \%$ & $33,3 \%$ & $53,3 \%$ & $100 \%$ & $86,6 \%$ & $86,6 \%$ & $100 \%$ & $86,6 \%$ & $86,6 \%$ \\
\hline
\end{tabular}

Peneliti melakukan pengujian lain menggunakan nilai threshold yang sama untuk semua citra uji, nilai threshold yang digunakan yaitu 133 didapat dari rata-rata hasil dari pengenalan pada tabel 1 .

Tabel 2 Presentase Pengenalan Threshold 133

\begin{tabular}{|c|c|c|c|c|c|c|c|c|c|c|}
\hline \multirow{3}{*}{$\begin{array}{c}\text { Citra } \\
\text { Uji ke- }\end{array}$} & \multirow{3}{*}{ Threshold } & \multicolumn{9}{|c|}{ Metode Ekstraksi Fitur } \\
\hline & & \multicolumn{3}{|c|}{ MSP } & \multicolumn{3}{|c|}{ SW } & \multicolumn{3}{|c|}{ MSP + SW } \\
\hline & & $K=3$ & $K=5$ & $K=7$ & $K=3$ & $K=5$ & $K=7$ & $K=3$ & $K=5$ & $K=7$ \\
\hline 1 & 133 & $\checkmark$ & $\checkmark$ & $\checkmark$ & $\checkmark$ & $\checkmark$ & $\checkmark$ & $\checkmark$ & $\checkmark$ & $\checkmark$ \\
\hline 2 & 133 & $x$ & $x$ & $x$ & $\checkmark$ & $x$ & $x$ & $\checkmark$ & $x$ & $x$ \\
\hline 3 & 133 & $\checkmark$ & $\checkmark$ & $\checkmark$ & $\checkmark$ & $\checkmark$ & $\checkmark$ & $\checkmark$ & $\checkmark$ & $\checkmark$ \\
\hline 4 & 133 & $x$ & $x$ & $x$ & $\checkmark$ & $x$ & $x$ & $\checkmark$ & $x$ & $x$ \\
\hline 5 & 133 & $x$ & $x$ & $\checkmark$ & $\checkmark$ & $\checkmark$ & $\checkmark$ & $\checkmark$ & $\checkmark$ & $\checkmark$ \\
\hline 6 & 133 & $x$ & $x$ & $x$ & $\checkmark$ & $\checkmark$ & $\checkmark$ & $\checkmark$ & $\checkmark$ & $\checkmark$ \\
\hline 7 & 133 & $x$ & $x$ & $x$ & $\checkmark$ & $\checkmark$ & $\checkmark$ & $\checkmark$ & $\checkmark$ & $\checkmark$ \\
\hline 8 & 133 & $x$ & $x$ & $x$ & $\checkmark$ & $\checkmark$ & $\checkmark$ & $\checkmark$ & $\checkmark$ & $\checkmark$ \\
\hline 9 & 133 & $x$ & $x$ & $x$ & $\checkmark$ & $\checkmark$ & $\checkmark$ & $\checkmark$ & $\checkmark$ & $\checkmark$ \\
\hline 10 & 133 & $x$ & $x$ & $x$ & $\checkmark$ & $\checkmark$ & $\checkmark$ & $\checkmark$ & $\checkmark$ & $\checkmark$ \\
\hline 11 & 133 & $x$ & $x$ & $x$ & $\checkmark$ & $\checkmark$ & $\checkmark$ & $\checkmark$ & $\checkmark$ & $\checkmark$ \\
\hline 12 & 133 & $\checkmark$ & $x$ & $x$ & $\checkmark$ & $\checkmark$ & $\checkmark$ & $\checkmark$ & $\checkmark$ & $\checkmark$ \\
\hline 13 & 133 & $\checkmark$ & $x$ & $\checkmark$ & $\checkmark$ & $\checkmark$ & $\checkmark$ & $\checkmark$ & $\checkmark$ & $\checkmark$ \\
\hline 14 & 133 & $x$ & $x$ & $x$ & $\checkmark$ & $\checkmark$ & $\checkmark$ & $\checkmark$ & $\checkmark$ & $\checkmark$ \\
\hline 15 & 133 & $x$ & $x$ & $x$ & $\checkmark$ & $\checkmark$ & $\checkmark$ & $\checkmark$ & $\checkmark$ & $\checkmark$ \\
\hline \multicolumn{2}{|c|}{ Rata-rata akurasi } & $26,7 \%$ & $13,3 \%$ & $26,7 \%$ & $100 \%$ & $86,6 \%$ & $86,6 \%$ & $100 \%$ & $86,6 \%$ & $86,6 \%$ \\
\hline
\end{tabular}

Karena nilai threshold berpengaruh ke konversi citra biner, maka dari hasil pada tabel 2 dapat disimpulkan bahwa dengan statistika warna dapat digunakan untuk mengklasifikasi citra rambu lalu lintas berdasarkan warna untuk mencari rambu peringatan, larangan atau perintah. Setelah itu, momen spasial dan momen pusat digunakan untuk pencarian bentuk atau objek dari citra yang dimasukkan ke aplikasi. Terlihat pada tabel 2 jika dibandingkan dengan tabel 1, hasil pengenalan lebih bagus pada tabel 1 karena pada pengujiannya menggunakan threshold yang menyesuaikan seleksi objek pada rambu lalu lintas.

\subsubsection{Pengujian Metode K-Nearest Neighbor dan Euclidean Distance}

Pengujian metode K-Nearest Neighbor merupakan simulasi perhitungan dari ekstraksi fitur data latih dengan data uji. Pengujian menggunakan citra data latih sebanyak 21 buah dan satu citra uji. Pada pengujian simulasi perhitungan ini data uji menggunakan threshold 75 menghasilkan ektraksi fitur pada tabel 3 dan citra hasil biner pada gambar 11.

Langkah-langkah pengujian citra dengan metode K-Nearest Neighbor dilakukan dengan urutan sebagai berikut :

1. Masukkan Citra

Masukkan citra uji dan berikan threshold bernilai 100 sehingga menghasilkan citra biner pada gambar 11 (kanan). 


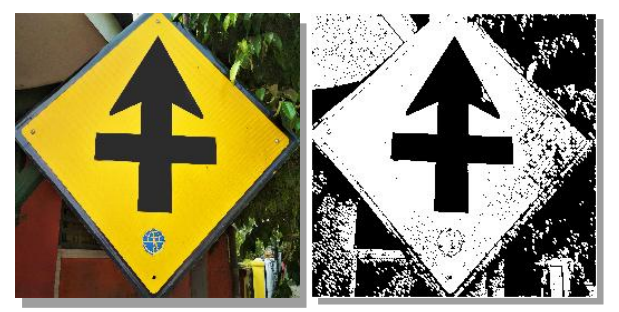

Gambar 11 Citra Asli (kiri) dan Citra Biner (kanan)

2. Tentukan Nilai K

Pada simulasi perhitungan ini peneliti menggunakan nilai $\mathrm{K}=5$.

3. Hitung Ekstraksi Fitur

Tekan tombol proses maka akan menghitung ektraksi fitur. Nilai ekstraksi fitur citra uji yang dihitung tertera pada tabel 3 .

Tabel 3 Ekstraksi Data Uji

\begin{tabular}{|c|c|c|c|c|c|}
\hline R_Red & R_Green & R_Blue & Dev_R & Dev_G & Dev_B \\
\hline 130.0 & 112.0 & 36.0 & 89.9966617 & 77.3127549 & 34.3286388 \\
\hline $\mathrm{N} 11$ & N02 & N20 & N03 & N30 & $\mathrm{N} 12$ \\
\hline 0.0151709 & 0.1338387 & 0.1244211 & 0.0020316 & 0.0077015 & -0.0028548 \\
\hline $\mathrm{N} 21$ & & & & & \\
\hline
\end{tabular}

Keterangan :

- N11, N02, N20, N03, N30, N12 dan N21 merupakan kolom ekstraksi fitur momen spasial dan momen pusat ternormalisasi.

- R_Red, R_Green, R_Blue merupakan rata-rata dari sebaran intensitas RGB setiap piksel dihitung dari persamaan 2.8 statistika warna.

- Dev_R, Dev_G, Dev_B merupakan standar deviasi RGB yang dihitung dari nilai rerata dari persamaan 2,9 statistika warna.

4. Hitung Nilai Jarak Euclidean

Menghitung hasil ekstraksi fitur citra uji dengan ekstraksi data latih menggunakan persamaan 1 dan simpan nilai ke basis data namun kolom peringkat masih kosong. Hasil perhitungan dapat dilihat pada tabel 4.

Tabel 4 Jarak Euclidean

\begin{tabular}{|c|c|r|r|l|}
\hline ID_det & ID_Uji & Euclidean & Target & Peringkat \\
\hline 1 & Uji_1 & 116,6455231 & 1 & \\
\hline 2 & Uji_1 & 124,2898102 & 1 & \\
\hline 3 & Uji_1 & 138,5784454 & 1 & \\
\hline 4 & Uji_1 & 114,6457596 & 1 & \\
\hline 5 & Uji_1 & 137,7447815 & 1 & \\
\hline 6 & Uji_1 & 100,3209915 & 1 & \\
\hline 7 & Uji_1 & 37,5792084 & 2 & \\
\hline 8 & Uji_1 & 47,2186432 & 2 & \\
\hline 9 & Uji_1 & 71,6607513 & 2 & \\
\hline 10 & Uji_1 & 29,4930973 & 2 & \\
\hline 11 & Uji_1 & 43,4338989 & 2 & \\
\hline
\end{tabular}




\begin{tabular}{|l|l|r|r|l|}
\hline 12 & Uji_1 & 29,0763969 & 2 & \\
\hline 13 & Uji_1 & 113,4697952 & 3 & \\
\hline 14 & Uji_1 & 100,1833878 & 3 & \\
\hline 15 & Uji_1 & 99,8655777 & 3 & \\
\hline 16 & Uji_1 & 113,9651184 & 3 & \\
\hline 17 & Uji_1 & 82,9838715 & 3 & \\
\hline 18 & Uji_1 & 105,4908524 & 3 & \\
\hline 19 & Uji_1 & 53,1637726 & 2 & \\
\hline 20 & Uji_1 & 99,5513611 & 3 & \\
\hline 21 & Uji_1 & 135,3760223 & 1 & \\
\hline
\end{tabular}

5. Urutkan Nilai Perhitungan Jarak

Berdasarkan jarak euclidean yang telah dihitung, kolom nilai euclidean terkecil akan diurutkan dan urutan peringkat diberikan seperti pada tabel 4.

Tabel 5 Urutan Jarak Euclidean

\begin{tabular}{|c|l|r|r|r|}
\hline ID_detail_Uji & ID_Uji & Euclidean & Target & Peringkat \\
\hline 12 & Uji_1 & 29,0763969 & 2 & 1 \\
\hline 10 & Uji_1 & 29,4930973 & 2 & 2 \\
\hline 7 & Uji_1 & 37,5792084 & 2 & 3 \\
\hline 11 & Uji_1 & 43,4338989 & 2 & 4 \\
\hline 8 & Uji_1 & 47,2186432 & 2 & 5 \\
\hline 19 & Uji_1 & 53,1637726 & 2 & 6 \\
\hline 9 & Uji_1 & 71,6607513 & 2 & 7 \\
\hline 17 & Uji_1 & 82,9838715 & 3 & 8 \\
\hline 20 & Uji_1 & 99,5513611 & 3 & 9 \\
\hline 15 & Uji_1 & 99,8655777 & 3 & 10 \\
\hline 14 & Uji_1 & 100,1833878 & 3 & 11 \\
\hline 6 & Uji_1 & 100,3209915 & 1 & 12 \\
\hline 18 & Uji_1 & 105,4908524 & 3 & 13 \\
\hline 13 & Uji_1 & 113,4697952 & 3 & 14 \\
\hline 16 & Uji_1 & 113,9651184 & 3 & 15 \\
\hline 4 & Uji_1 & 114,6457596 & 1 & 16 \\
\hline 1 & Uji_1 & 116,6455231 & 1 & 17 \\
\hline 2 & Uji_1 & 124,2898102 & 1 & 18 \\
\hline 21 & Uji_1 & 135,3760223 & 1 & 19 \\
\hline 5 & Uji_1 & 137,7447815 & 1 & 20 \\
\hline 3 & Uji_1 & 138,5784454 & 1 & 21 \\
\hline & & & & \\
\hline
\end{tabular}

6. Ambil Data Klasifikasi Berdasarkan Nilai K

Dengan menggunakan nilai $\mathrm{K}=5$, maka didapatkan klasifikasi anggota nilai $\mathrm{K}$ yang dapat dilihat pada tabel 5 . 
Tabel 6 Klasifikasi Nilai K

\begin{tabular}{|c|c|c|c|}
\hline ID_detail_Uji & Euclidean & Target & Peringkat \\
\hline 12 & 29.0763969 & $\mathbf{2}$ & 1 \\
\hline 10 & 29.4930973 & $\mathbf{2}$ & 2 \\
\hline 7 & 37.5792084 & $\mathbf{2}$ & 3 \\
\hline 11 & 43.4338989 & $\mathbf{2}$ & 4 \\
\hline 8 & 47.2186432 & $\mathbf{2}$ & 5 \\
\hline
\end{tabular}

7. Kesimpulan Target Terbanyak Berdasarkan Klasifikasi Nilai K

Tabel 5 menunjukan bahwa didapat target terbanyak yaitu nilai 2 sebanyak 5 pada klasifikasi nilai $\mathrm{K}=5$, maka selanjutnya program akan mengambil rambu lalu lintas yang memiliki target atau ID_R=2 (gambar 12). Karena proses pengujian antara citra uji dengan citra hasil pengenalan luarannya sama, pengujian ini dapat dinyatakan sebagai "Dikenali" atau dengan mengkonfirmasi radiogroup "YA".

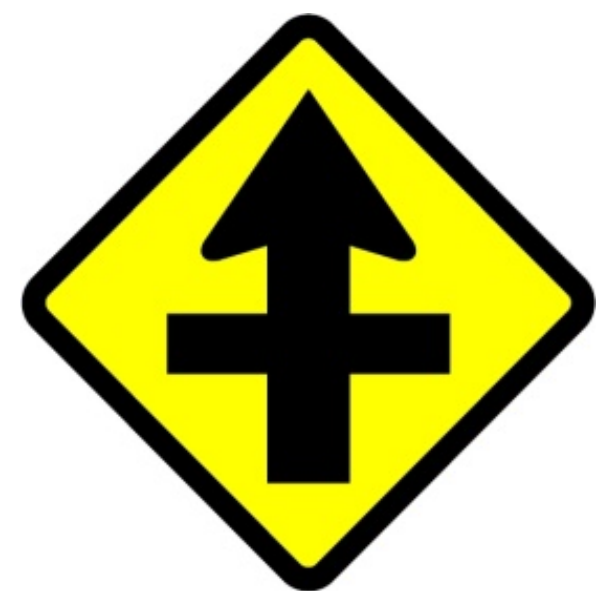

Gambar 12 Rambu Peringatan Simpang Empat Prioritas

\section{KESIMPULAN}

Berdasarkan hasil penelitian tentang pengenalan citra rambu lalu lintas menggunakan metode K-Nearest Neighbor dan Euclidean Distance dapat diambil kesimpulan yaitu aplikasi dapat menampilkan hasil pengenalan citra salah satu dari tiga jenis rambu lalu lintas yang dipakai lengkap dengan informasi tentang rambu lalu lintas seperti arti rambu, tipe rambu dan lain sebagainya.Faktor yang dapat mempengaruhi pengenalan citra yaitu adalah intensitas cahaya, komposisi warna, kontras, debu, bayangan objek lain seperti daun dan posisi saat gambar di foto. Nilai threshold menjadi faktor yang mempengaruhi hasil konversi biner yang digunakan untuk ektraksi fitur momen spasial dan momen pusat ternormalisasi. Kemudian berdasarkan jumlah data citra latih sebanyak 21 citra dan data citra uji sebanyak 15 menggunakan ekstraksi fitur statistika warna, momen spasial dan momen pusat ternormalisasi dengan pengujian nilai $\mathrm{K}=3,5$ dan 7, didapat akurasi tertinggi pada nilai $\mathrm{K}=3$ yaitu sebesar $100 \%, 86,6 \%$ untuk nilai $\mathrm{K}=5,86,6 \%$ untuk nilai $\mathrm{K}=7$ dan $91,1 \%$ untuk total keseluruhan citra uji sebanyak 15 citra. 


\section{UCAPAN TERIMA KASIH}

Terima kasih saya ucapkan kepada pembimbing penulis dalam penelitian ini dan kepada dosen program studi Informatika Universitas Teknologi Yogyakarta yang sudah membantu dalam proses penelitian dan perkuliahan penulis. Terima kasih kepada bapak ibu segenap keluarga dan teman-teman yang sudah memberikan berbagai bentuk semangat selama penulis melakukan penelitian ini.

\section{DAFTAR PUSTAKA}

[1] Munir, R. (2004), Pengolahan Citra Digital dengan Pendekatan Algoritmik, Cetakan Pe Bandung: Informatika Bandung.

[2] Bahri, R.. dan Maliki, I. (2012), Perbandingan Algoritma Template Matching dan Feature Extraction pada Optical Character Recognition, Jurnal Komputer dan Informatika, 1, 2935.

[3] Wirjaputra, A. (2012), Mengungkap Teknologi “Google Autonomous Car," Diambil darihttp://comp-eng.binus.ac.id/files/2012/06/Mengungkap-Teknologi-Google-

Autonomous-Car-Andrew-W.pdf (akses 10 Desember 2018).

[4] Dewi, M.. Kesiman, W.. dan Sunarya, I.M.. (2014), Aplikasi Pembelajaran Pengenal Aksara Bali, Jurnal Nasional Pendidikan Teknik Informatika (JANAPATI), 41-50.

[5] Kadir, A. dan Susanto, A. (2013), Teori dan Aplikasi Pengolahan Citra, D. Hardjono, Ed. Andi Offset.

[6] Karimah, F.U. (2014), Rancang Bangun Aplikasi Pencarian Citra Batik Besurek Berbasis Tekstur Dengan Metode Gray Level Co-Occurence Matrix dan Euclidean Distance, Universitas Bengkulu.

[7] Romadhon, G. dan Murinto (2014), Aplikasi Pengenalan Citra Rambu Lalu Lintas Berbentuk Lingkaran Menggunakan Metode Jarak City-Block, Jurnal Sarjana Teknik Informatika, 2(2).

[8] Listyanto, S.R. (2015), Implementasi K-Nearest Neighbor Untuk Mengenali Pola Citra Dalam Mendeteksi Penyakit Kulit, Universitas Dian Nuswantoro Semarang.

[9] Rosyidi, A. Ginardi, H. dan Munif, A. (2017), Implementasi Metode K-Nearest Neighbor Untuk Penentuan Lokasi Pos Hujan Terdekat Dengan Titik Rute Perjalanan Pada Aplikasi Clearroute, Jurnal Teknik ITS, 6(2).

[10] Swedia, E.R. Septian, M.R.D. dan Cahyanti, M. (2017), Aplikasi Pendeteksi Rambu LaluLintas Menggunakan Operator Sobel dan Metode Hamming, Universitas Gunadarma. 